\title{
Development of Biotechnology Textbook Based on Bioinformatics Research
}

\author{
Dian Eka Aprilia Fitria Ningrum, Imam Rofiki*, Vannisa Aviana Melinda, \\ Imroatul Hayyu Erfantinni, Roiyan One Febriani
}

Faculty of Tarbiyah and Teacher Training, Universitas Islam Negeri Maulana Malik Ibrahim Malang, Indonesia

Received June 20, 2020; Revised August 27, 2020; Accepted September 11, 2020

\section{Cite This Paper in the following Citation Styles}

(a): [1] Dian Eka Aprilia Fitria Ningrum, Imam Rofiki, Vannisa Aviana Melinda, Imroatul Hayyu Erfantinni, Roiyan One Febriani , "Development of Biotechnology Textbook Based on Bioinformatics Research," Universal Journal of Educational Research, Vol. 8, No. 11, pp. 5188-5196, 2020. DOI: 10.13189/ujer.2020.081119.

(b): Dian Eka Aprilia Fitria Ningrum, Imam Rofiki, Vannisa Aviana Melinda, Imroatul Hayyu Erfantinni, Roiyan One Febriani (2020). Development of Biotechnology Textbook Based on Bioinformatics Research. Universal Journal of Educational Research, 8(11), 5188-5196. DOI: 10.13189/ujer.2020.081119.

Copyright $\odot 2020$ by authors, all rights reserved. Authors agree that this article remains permanently open access under the terms of the Creative Commons Attribution License 4.0 International License

\begin{abstract}
Learning for undergraduate students needs to pay attention to the development of science and technology. Based on the results of the Biotechnology level of undergraduate students' needs assessment, it is known that the teaching materials have not used the bioinformatics approach. However, bioinformatics is a significant study in this course. One of the alternatives to achieve the goal of learning is to develop textbook-based research. The textbook was designed based on research on the potential analysis of quercetin compounds in apples as anti-autism by reverse docking. The study aims to develop a textbook for the biotechnology course. The method to the development of a textbook on this research used a development of Dick \& Carey model. The study involved 3 students for the individual test, and 9 students for small group test. The results of validation from the material expert, media expert, and learning practitioner are $96 \%$, $91 \%$, and $93 \%$, while the results of students' tests are individual test $84 \%$ and small group test $86 \%$. All validation results show a very valid category with revisions according to expert advice and readability from students. The textbook developed can be used as materials for undergraduate students in courses relevant to the content of textbook, especially Biotechnology courses in the Biology Education department.
\end{abstract}

Keywords Bioinformatics, Research and Development, Silico Research, Textbook, Undergraduate Students

\section{Introduction}

Biology Education Study Program students are expected to actively develop their potential along with the development and progress of the Science and Technology by examining the branch of science that is occupied. One of the branches of science closely related to technology and science is Biotechnology [1]. Biotechnology reviews the application of technology associated with being alive to create/modify a product/process with the particular purpose [2]. The development of biotechnology is rushing along with the development of the times. The development of biotechnology is accompanied by new research technology developing and the availability of "big data" [3]. Thus, biotechnology needs to be given to the student education biology.

Biotechnology is one of the courses in Biology Education Study Program, State University of Malang. Based on the results of studies preliminary to the subjects Biotechnology, discussion material Biotechnology in the lecture has already contextualized several fields such as pharmacy, medicine, agriculture, animal husbandry, and forensics by using the method of presentation, discussion, fieldwork, and laboratory activities. The application of biotechnology is expected to provide a solution to overcome the various problems facing a human. For example, the availability of food, energy, and medicine 
into the issue is crucial because it directly relates to the need for fundamental human [4].

Biotechnology learning based on the Bioinformatics approach is an applied learning innovation following the development of science and technology to achieve the expected competencies. Based on the observation that the lecturer suggested biotechnology book by Thieman [5], entitled Introduction of Biotechnology and Schmid [6], entitled Biotechnology has been discussed a little about bioinformatics. Bioinformatics is the science that applies information technology, namely computing and communication technology, especially the internet, to biological science [7]. There are three objectives of Bioinformatics, namely: (1) organize the data to access the information that exists or convey the data just from the results of the research, (2) develop tools and resources that assist in analyzing the data, and (3) analyze the data and interpret the results in biological content [8].

The use of research data is also expected to provide contextual examples so that students' understanding of biotechnology concept becomes deeper. This is by the results of student questionnaires, namely $95 \%$ of students stated that they need to develop textbook based on bioinformatics research because they follow the development of science and technology, add insight, and innovation in learning. The development of the textbook based on research has been proven to inspire students to find the idea of creativity and innovation in solving problems in society [9].

We got the information based on interviews to the lecturer of the Biotechnology course that the need for additional sources of learning that is contextually relevant research in Biotechnology. Development of textbook needed to enrich, add, or deepen the knowledge of learners [10]. Hence, the purpose of the study is to develop a textbook for the biotechnology course.

The textbook was developed based on the stages of the development of Dick \& Carey model [11]. The selection model of development is based on: (1) the existence of juxtaposition tight between the results of learning, characteristics of participants learners, activity/activities of learning, and assessment, (2) their relationship in each component, in particular the relationship between the strategy of learning and outcomes of learning are desired, and (3) the use of the data of empirical and process that can be repeated so that when there is a shortage in product, development can be straight to be fixed. The development of this research-based textbook can improve student learning outcomes in the field of biotechnology. Thereby strengthening the development of education is based on the latest biological scientific developments [12-14].

\section{Textbooks}

Learning books are a tool used by students to achieve learning goals. There are two types of learning books, namely textbooks and non-textbooks. Textbooks are the primary tool supporting the implementation of the curriculum, while non-textbooks are an additional means to facilitate the development of learning [15]. Textbooks contain knowledge material that is studied up to the evaluation instruments [16]. At the same time, non-textbooks are not equipped with evaluation instruments and the like which require the reader to carry out the instructions expected by the author.

Non-textbooks consist of enrichment books, reference books, and educator manuals. Both textbooks and non-textbooks must meet the criteria for books that are fit for use by the education unit by the Ministry of Education and Culture Regulation No. 8 of 2016. Criteria for evaluating book quality, according to the Minister of Education and Culture of the Republic of Indonesia [17], include the appropriateness of contents/material, presentation, language, and graphic. The details of the four aspects are as follows.

The material aspects include:

(1) The material, data, and concepts presented are true and accurate and support national education goals.

(2) The source of matter is theoretically and empirically correct.

(3) Students can be encouraged to be independent, innovate, and develop themselves.

(4) The contents of the material can maintain the unity and integrity of the nation with diversity, cooperation, and respect for differences.

The material presentation aspects include:

(1) The material presented is coherent, coherent, straightforward, easy to understand, and interactive, so that the integrity of meaning can be conveyed.

(2) Presentation of material illustrations in the form of text or images that aim to clarify the content must be by the level of development of students and do not contain elements of pornography, extremism, radicalism, violence, racial intolerance, gender bias, and other deviations.

(3) The presentation of material can stimulate students to think critically, creatively, and innovatively.

(4) The presentation of the material is contextually to encourage students to explore positive things in everyday life.

(5) The presentation of the material is attractive so that it arouses curiosity for the reader.

The linguistic aspects include:

(1) The language used is precise, straightforward, transparent, and by students' level of development.

(2) Illustration of material in the form of text or images aims to clarify the content must be by the level of development of students.

(3) The language used is communicative and informative with educational, polite, ethical, and aesthetic characteristics so that it contains positive 
messages according to the level of student development.

(4) Book titles and subtitles in it are in harmony and can attract students' interest in reading and are not provocative.

The graphic aspects include:

(1) The size of the is appropriate to the content and level of development of students.

(2) Display of harmonious book skin layout showing unity.

(3) Giving a harmonious color and can clarify the function.

(4) The selection of type and size of letters takes into account the level of development of students.

(5) The use of illustrations aims to clarify the message conveyed.

Textbooks are a means for writers to document research results, observations, and the actualization of experiences that refer to the curriculum. The development of textbooks is to increase the availability of books according to curriculum demands, target characteristics (students), and demands for problem-solving learning [18]. Textbooks that are developed do not have to be essential books (textbooks), but can also be used as supplementary books (non-textbooks) to enrich, add to or deepen students' knowledge [18].

Basically, textbooks can provide experience, knowledge, and skills to students about life in various fields, both about themselves, society, culture, nature around them, and about God who created all of that [16]. Biology, as a branch of science, is very accommodating of all these things because it examines all matters relating to living things and life. Three awareness must be possessed to succeed in learning and learning Biology, namely (1) aware of what Biology is learning, (2) aware of the need for scientific content, and (3) aware of how to learn or teach in the right way/technique [14]. By understanding that awareness, it is expected that Biology can solve various problems in life in order to improve the welfare of life. These problems such as food, clothing, housing, energy, environment, medicine, and even social issues, can be overcome with Biology [13].

\section{Methods}

The type of this study is Research and Development ( R \& D) with the development of Dick \& Carey model [11]. The Dick \& Carey model consists of ten stages, namely (1) identify instructional goals, (2) conduct instructional analysis, (3) analyze Learners and Contexts, (4) write performance objectives, (5) develop assessment instruments, (6) develop instructional strategy, (7) develop and select instructional materials, (8) design and conduct a formative evaluation of instruction, (9) revise instruction, and (10) design and conduct summative evaluation [11]. In the study, it is limited only to stage 9 because on stage 9 product developed has been through the stages of evaluation and revision of the contents related to the product's effectiveness.

The study produced a textbook that was tested to the undergraduate students of Biology department at State University of Malang, Indonesia. Tests for students were carried out in two stages, individual test and small group test. The individual test consists of 3 students, and a small group test consists of 9 students. Before being tested, the textbook will be validated by 3 experts, namely material expert, media, and learning practitioners. Material expert validated the content of the textbook. Media expert validated the product layout of the textbook. Learning practitioner is a lecturer who teaches biotechnology in undergraduate students. Learning practitioners validated the function of the textbook in lecturing. Instrument of validation was modified from Badan Standar Nasional Pendidikan (BSNP). The instrument for testing to students was modified from Dick \& Carey [11]. Type of data involves data quantitatively that was obtained from sheets of validation in the form of a score with a scale of 1-4, and the data qualitatively were obtained from responses validator experts and students are in the form of comments, criticism-suggestion, and repairs were written on sheets of validation.

The data analysis technique in this study is a descriptive statistical analysis technique. It is used to process data obtained from a questionnaire and presented as a percentage. The analysis results are then inferred based on the criteria of validity that were adapted from Akbar [19]. The results of the validation of material expert, especially the truth of the material, must reach $100 \%$.

\section{Results}

Data obtained from this study are data from experts and test data on students. The following results are obtained.

\subsection{Data from Expert}

\subsubsection{Material Expert}

The assessment by the material expert is divided into three components, namely the appropriateness of the content, the appropriateness of the language, and the appropriateness of the presentation. Data validation results by the material expert can be seen in Table 1 .

The result of the validation by material expert was $96 \%$. Based on the validity criteria adapted from Akbar [19], the result indicates that the textbook developed is very valid, so that it can be used but after it has been revised based on suggestions from material expert. The average value of each component shows that the material presented in the textbook is very good, both in terms of the accuracy of the material, the language used, and the book's appearance. 
Table 1. Data Validation Results by Material Expert

\begin{tabular}{|c|c|c|c|c|c|}
\hline No & Component & Sub Component & Total Score & Max Score & $\begin{array}{c}\text { Validity Criteria } \\
(\%)\end{array}$ \\
\hline \multirow{3}{*}{1} & \multirow{3}{*}{ Content eligibility } & $\begin{array}{l}\text { The suitability of the material with the } \\
\text { learning objectives }\end{array}$ & 11 & 12 & $x_{2}$ \\
\hline & & Material accuracy & 12 & 12 & 100 \\
\hline & & Supporting material & 16 & 16 & 100 \\
\hline \multirow{6}{*}{2} & \multirow{6}{*}{ Language Feasibility } & Conformity with student development & 7 & 8 & 87.5 \\
\hline & & Legibility & 4 & 4 & 100 \\
\hline & & Straightforwardness & 6 & 8 & 75 \\
\hline & & Coherence & 8 & 8 & 100 \\
\hline & & Conformity of language rules & 8 & 8 & 100 \\
\hline & & Use of terms/symbols & 11 & 12 & 92 \\
\hline \multirow{4}{*}{3} & \multirow{4}{*}{ Feasibility of presentation } & Presentation technique & 11 & 12 & 92 \\
\hline & & Supporting the presentation & 16 & 16 & 100 \\
\hline & & Completeness of presentation & 20 & 20 & 100 \\
\hline & & Total & 130 & 136 & 96 \\
\hline
\end{tabular}

Table 2. Data Validation Results by Media Expert

\begin{tabular}{|c|c|c|c|c|c|}
\hline No & Component & Sub Component & Total Score & Max Score & Validity Criteria (\%) \\
\hline \multirow{3}{*}{1} & \multirow{3}{*}{ Feasibility of graphics } & Book size & 8 & 8 & 100 \\
\hline & & Book cover design & 64 & 72 & 89 \\
\hline & & Design the contents of the book & 123 & 136 & 90 \\
\hline \multirow{3}{*}{2} & \multirow{3}{*}{ Feasibility of presentation } & Presentation technique & 12 & 12 & 100 \\
\hline & & Supporting the presentation & 14 & 16 & 87.5 \\
\hline & & Completeness of presentation & 20 & 20 & 100 \\
\hline \multicolumn{3}{|c|}{ Total } & 241 & 264 & 91 \\
\hline
\end{tabular}

\subsubsection{Media Expert}

Evaluation by media expert is divided into two components, namely the feasibility of graphics and the feasibility of presentation. Data from the validation by media expert can be seen in Table 2 .

The validation result by media expert is $91 \%$. Based on the validity criteria adapted from Akbar [19], the result indicates that the textbook developed is very valid, so that they can be used but after revision based on advice from media expert. The average value of each component shows that the layout presented in the textbook is very good, both in terms of book size, book design, and completeness of the book.

\subsubsection{Learning Practitioners}

Assessment by learning practitioner is divided into three components, namely the clarity of textbooks, the effect on students, and feasibility. Data validation results by learning practitioner can be seen in the following Table 3 .
Table 3. Data Validation Results by Learning Practitioner

\begin{tabular}{ccccc}
\hline No & Component & $\begin{array}{c}\text { Total } \\
\text { Score }\end{array}$ & $\begin{array}{c}\text { Max } \\
\text { Score }\end{array}$ & $\begin{array}{c}\text { Validity } \\
\text { Criteria } \\
\text { (\%) }\end{array}$ \\
\hline 1 & Clarity of textbooks & 43 & 44 & 98 \\
\hline 2 & $\begin{array}{c}\text { Influence on } \\
\text { students }\end{array}$ & 17 & 20 & 85 \\
\hline 3 & $\begin{array}{c}\text { Possibility } \\
\text { (feasibility })\end{array}$ & 18 & 20 & 90 \\
\hline Total & $\mathbf{7 8}$ & $\mathbf{8 4}$ & $\mathbf{9 3}$ \\
\hline
\end{tabular}

The result of the validation by learning practitioner was 93\%. Based on the validity criteria adapted from Akbar [19], the result indicates that the textbook developed is very valid, so that it can be used but after it has been revised based on suggestions from learning practitioner. The average value of each component after using the book shows good grades. The lecturer judges in terms of clarity of the book and how far it can affect students in learning to use the book. 


\subsection{Test Data on Students}

Tests for students were carried out in two stages, individual test and small group test. The test on students consists of three components, namely the clarity of textbooks, the effect on students, and feasibility. Data on individual test results can be seen in Table 4, while data on small group test results can be seen in Table 5 .

Table 4. Data on Individual Test Results

\begin{tabular}{ccccc}
\hline No & Component & $\begin{array}{c}\text { Total } \\
\text { Score }\end{array}$ & $\begin{array}{c}\text { Max } \\
\text { Score }\end{array}$ & $\begin{array}{c}\text { Validity } \\
\text { Criteria } \\
\mathbf{( \% )}\end{array}$ \\
\hline 1 & Clarity of textbooks & 110 & 132 & 83 \\
\hline 2 & $\begin{array}{c}\text { Influence on } \\
\text { students }\end{array}$ & 50 & 60 & 83 \\
\hline 3 & $\begin{array}{c}\text { Possibility } \\
\text { (feasibility) }\end{array}$ & 51 & 60 & 85 \\
\hline & Total & $\mathbf{2 1 1}$ & $\mathbf{2 5 2}$ & $\mathbf{8 4}$ \\
\hline
\end{tabular}

The percentage of an individual test was $84 \%$. Based on the validity criteria adapted from Akbar [19], this result indicates that the textbook developed is quite valid. Therefore, it can be used but after a small revision based on suggestions from students.

Table 5. Small Group Test Result

\begin{tabular}{ccccc}
\hline No & Component & $\begin{array}{c}\text { Total } \\
\text { Score }\end{array}$ & $\begin{array}{c}\text { Max } \\
\text { Score }\end{array}$ & $\begin{array}{c}\text { Validity } \\
\text { Criteria } \\
(\mathbf{\%})\end{array}$ \\
\hline 1 & $\begin{array}{c}\text { Clarity of } \\
\text { textbooks }\end{array}$ & 344 & 396 & 87 \\
\hline 2 & $\begin{array}{c}\text { Influence on } \\
\text { students }\end{array}$ & 156 & 180 & 87 \\
\hline 3 & $\begin{array}{c}\text { Possibility } \\
\text { feasibility })\end{array}$ & 154 & 180 & 85.5 \\
\hline & Total & $\mathbf{6 5 4}$ & $\mathbf{7 5 6}$ & $\mathbf{8 6}$ \\
\hline
\end{tabular}

The percentage of a small group test was $86 \%$. Based on the validity criteria adapted from Akbar [19], this result indicates that the textbook developed is very valid. Hence, it can be used but after it has been revised based on suggestions from students.

Students' average value of each component both individual and small group assessments after using the book shows good grades. Students judge in terms of the book's clarity and how far it can affect students in learning to use the book.

\section{Discussion}

The development of this research-based textbook uses the Dick and Carey floating model [11]. The textbook product developed was validated by material expert, the media, and learning practitioner and was tested by individuals and small groups of undergraduate students in Biology Education study programs who acted as users. The validation test is done by involving experts, users, and audiences $[19,20]$. Expert is someone who is competent in his field, in this study the validation of experts by material and media experts. The user is an educator who later uses this textbook in teaching practice, in this study the user is a Biotechnology lecturer. Audience is students who study with textbooks, in this study the audience is the students of Biology Education Study Program. Validation is done to assess the feasibility of the textbook before use. Textbook validation is an effort to produce books with high validity through validation test [19]. The validation results follow the validity criteria adapted from Akbar [19].

The results of the validation of material expert, especially the truth of the material, must reach $100 \%$. This condition is intended so that there is no misconception to students as users. The writer textbooks need correctness and the accuracy of the information is submitted under the relevant disciplines [21]. This research-based textbook has reached $100 \%$ for the sub-component of material accuracy (Table 1) by revising according to the material expert's advice.

The overall results of the material expert validation of the textbook developed were $96 \%$ with a very valid category, but there needs to be some revisions. Revisions are made by taking into account the advice of material expert. In the component of content eligibility, the material expert has provided some suggestions for improvement, such as correcting the wrong concept, writing the wrong term, and the chapter's order in the textbook. Advice from material expert, the order of the chapters should be: (1) biotechnology, (2) autism, and (3) bioinformatics. This means that students are coherent in learning it. Students are introduced to biotechnology products in the pharmaceutical field initially, then to get to know one of the problems in the health sector, namely autism, then to recognize one alternative solution to solve the problem through bioinformatics. The author will be presented with three basic questions when writing: what to write, who read it, and how writing [22]. All three initial questions can be answered by the curriculum [21]. Thus the curriculum is the primary reference in writing textbooks.

In the component of language eligibility, advice from material expert is that there are incorrect terms in describing the contents of the material and some non-standard words. An example of using the wrong term is that in discussing material about vaccines, the writer uses the pronoun "antigen". It is better to keep using "vaccine" to confuse students. Examples of non-standard words "suspected" should be removed. In the presentation's feasibility component, advice from material expert is that each picture should have an explanation in the text section. For example, the material expert recommended to provide a detailed description related to an image. This is based on why the authors accentuate to show that biotechnology covers several branches of science. The revision result is based on expert's advice, as shown in Figure 1. 


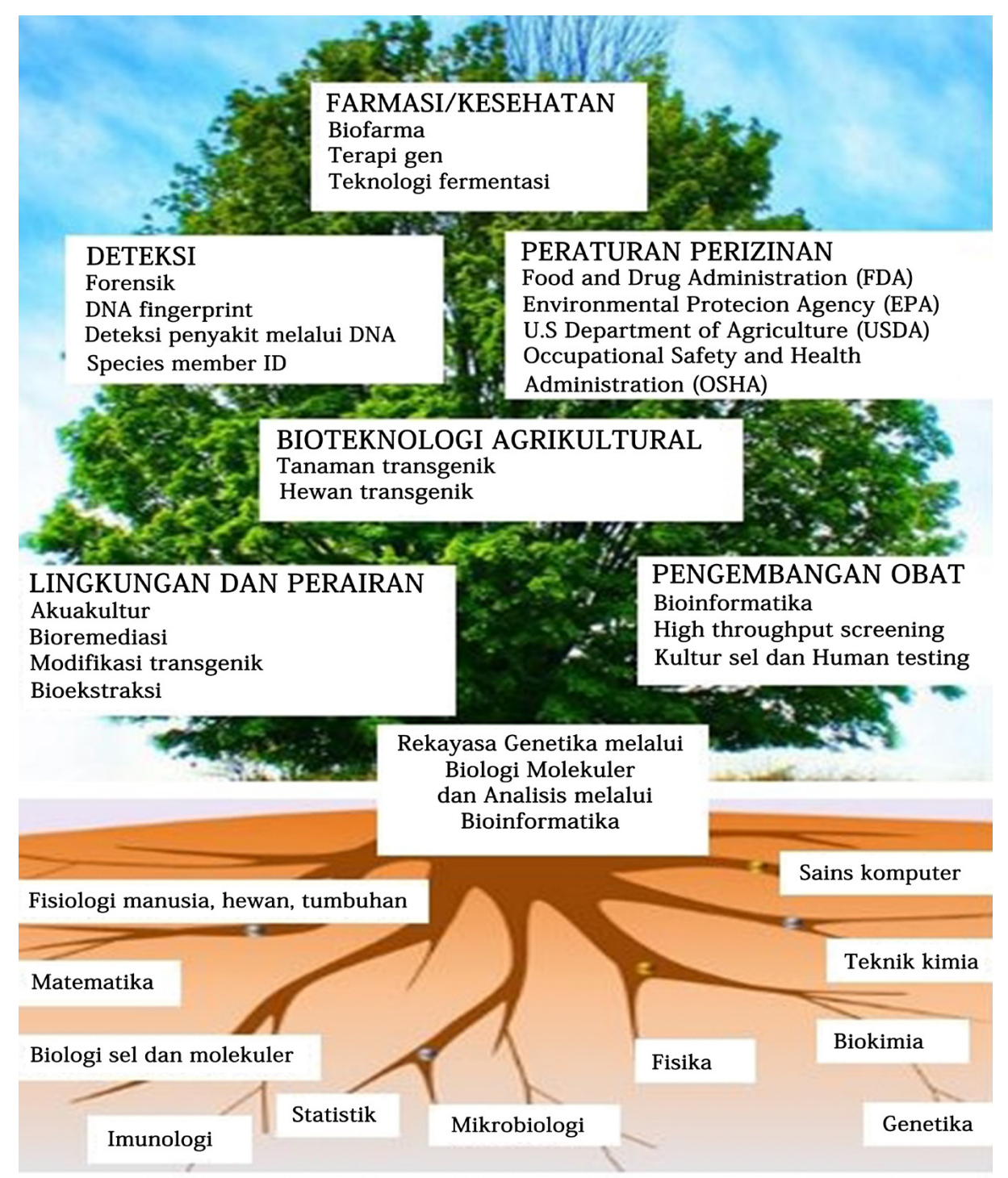

Figure 1. Revision Results Based on Expert Advice

The validation of the media expert against the textbook developed was $91 \%$ with a very valid category, but there needs to be some revisions. Revisions are made concerning advice from media expert. In the feasibility component of graphics, media expert has provided some suggestions for improvements such as writing the study program's identity on the cover. The use of decorative letters should be avoided, displaying a table of contents, clarity of images, and identity of pictures and tables.

Improvements to the type of font used are for writing the preface and table of contents, while the improvement in font size used is in writing the table. The textbook developed have used standard font sizes of $12 \mathrm{pt}$ for text and 10pt for tables and figures with Times New Roman font models. Improvements to the image's illustration are done by replacing images that are less clear and unattractive because of black and white. Role illustration image in textbooks, namely: causing interest and motivation, attractive and directing your attention, helping learners understand concepts that are difficult to explain with words, assisting learners slow reading, and helping remember longer [21]. Improvements to the table of contents are to change the layout of the table of contents to be more informative. The table of contents in the textbook helps educators show students which part is being studied [23].

In the presentation's feasibility component, the authors have used various sources of information such as printed books, e-books, internet media, and research articles. The book's contents would be very good if using references edge that has relevance from various sources such: books, internet, magazines, and journals results of research [18]. Another improvement is the instructions for using teaching materials; in some parts, they do not contain instructions for students, so the authors make improvements according to the advice of media expert.

The results of the learning practitioners' validation of the textbook developed were $93 \%$ with a very valid 
category, but there needed to be some revision. The revision was made by taking into account the suggestions of learning practitioners. The main thing suggested by learning practitioners is about the use of bioinformatics in undergraduate students, whether it is in accordance with the level. The authors intend to provide additional knowledge to undergraduate students regarding in silico research (Figure 2) which can be used as biotechnology tool in the pharmaceutical field, especially in predicting bioactive compounds to treat certain diseases.

Another improvement suggested by learning practitioners is the provision of phytopharmaca drug samples as additional information obtained by students as users. Adding information about preclinical testing and clinical trials is also a suggestion for improvement from learning practitioners because it is in line with the topic of pharmaceutical bioinformatics in the field of medicine.

a. Visualisasi ikatan ligan quercetin dengan protein carbonic anhydrase 2 .

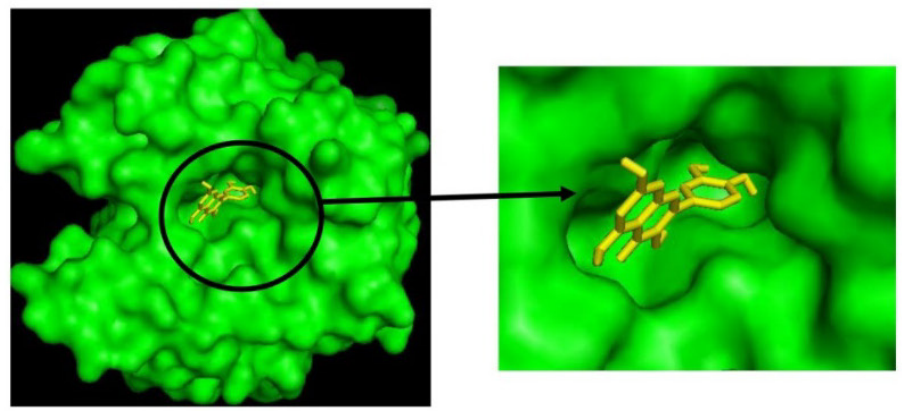

b. Visualisasi ikatan ligan topiramate dengan protein carbonic anhydrase 2 .

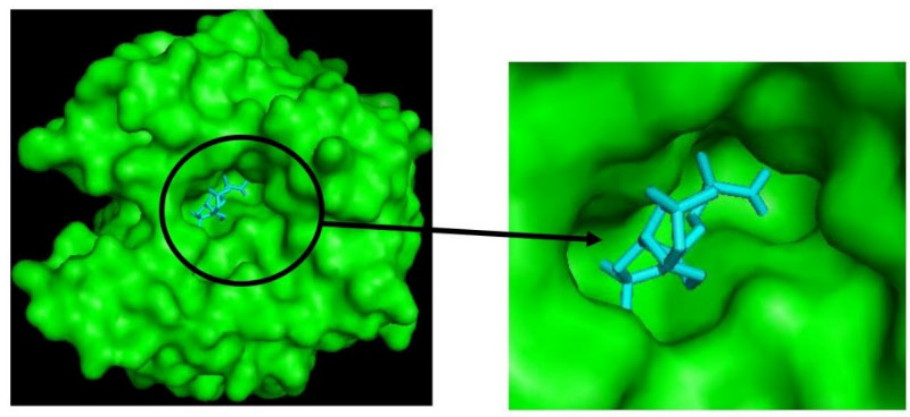

c. Visualisasi ikatan ligan zonisamide dengan protein carbonic anhydrase 2.

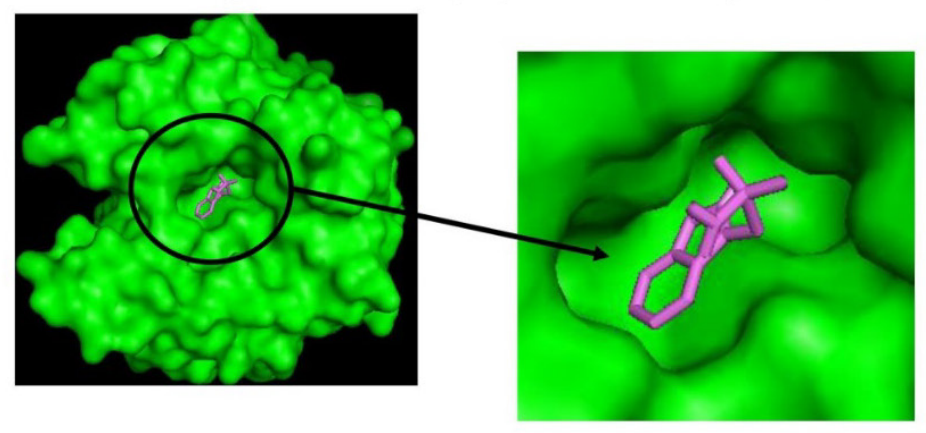

Bab 3 Bioinformatika

Figure 2. Contents of the Book Regarding in Silico Research 
The next discussion is trials conducted on students, including individual tests with 3 students who have not taken Biotechnology courses and small group tests with 9 students who have taken Biotechnology courses. The selection of the number of test subjects and class of students (not yet taken and have taken Biotechnology courses) is based on the instructions in the model development of Dick and Carey [11]. Individual tests aim to eliminate obvious errors, including errors in writing, image presentation, clarity of features in books, and. Therefore, the study used groups of students who have never taken Biotechnology courses as users who learn new knowledge and new skills. Small group tests aim to determine the effectiveness of changes made after individual tests, and whether students can use the book without interacting with the authors, therefore it is used groups of students who have taken Biotechnology courses as users who already have preliminary knowledge about biotechnology.

The results of individual tests of textbook developed were $84 \%$ with a category that is quite valid so there needs to be some revisions. Revisions were made, taking into account the advice of individual tests. The suggestion obtained from individual test results is that the book size is too large. The authors do not change the book's size based on the consideration that the images in it make it look clear. Students do not write other corrections in the suggestion column on the test sheet. Students write that the books developed have been good and increase student knowledge.

The results of small group tests on textbook developed were $86 \%$ with a very valid category, but there needs to be some revisions. Revisions were made taking into account the advice of small group tests. In the textbook clarity component, suggestions from students are to improve writing that is less contrasting with the background and improve unclear images. In the aspect of influence on students, students convey that the information presented is good, there are applicable activities, and the layout is appropriate. In the aspect of possibility (feasibility), advice from students is the suitability of the time needed to learn to use this teaching material is enough if applied in learning. The authors believe that this book can be used as a project activity for undergraduate students in groups, so that if you apply in silico process not when face to face in class. Students also think that the book developed has motivated students to find out more.

Overall, the results of the validation and trial of this research-based Biotechnology textbook are very valid and can be used in the Biotechnology learning process after going through revisions in accordance with the qualitative data obtained. This shows that this research-based textbook is in accordance with the curriculum in Indonesia so that it can support students in achieving learning outcomes, especially in Biotechnology courses. The development of this latest research-based textbook can improve student learning outcomes in the field of biotechnology, thereby strengthening the development of education is based on the latest biological scientific developments [12-14].

Research-based textbooks have been widely carried out and have benefits including (1) contextual because students are invited to apply concepts that have been theoretically obtained with the latest research data [24], (2) can develop academic skills in exploring and utilizing information [25], (3) is the result of scientific integration by the competency needs that students must master [26], (4) facilitating students to understand the material by completing research work procedures in the laboratory, so that they can shape their life skills [27]. Textbooks that are based on this latest biology-based research development can be used not only in Biotechnology courses, but in other relevant subjects, such as bioinformatics, cell biology, plant physiology, and so on.

\section{Conclusions}

Textbook generated has been revised in accordance suggestion of validator and result test to students. The use of research-based biotechnology textbooks on a broader scale needs to pay attention to the following points: 1) Research-based biotechnology textbooks are developed for undergraduate students of Biology Education Study Program, State University of Malang. The use of textbooks on a wider scale needs to review the appropriateness of the books with the target users; 2) The development of this research-based Biotechnology textbook only reaches the 9 th stage of the 10 stages of the Dick and Carey development model, so that further testing is needed for widespread use.

\section{Acknowledgments}

We are very grateful to experts for validation of textbook-based research and participants for supporting research. We are also very thankful to reviewers and editors of this journal for their suggestions to improve this article.

\section{REFERENCES}

[1] A. Bartoszek, A. Bekierska, J. Bell-lloch, T. de Groot, E. Singer, and M. Wozniak, Managing Innovations in Biotechnology: European Project Semester 2006. Lisbon: Lisbon Agenda, 2006.

[2] F. Mahboudi, H. Hamedifar, and H. Aghajani, "Medical Biotechnology Trends and Achievements in Iran," Avicenna J. Med. Biotechnol., vol. 4, no. 4, pp. 200-205, 2012. 
[3] A. L. Oliveira, "Biotechnology, big data and artificial intelligence," Biotechnol. J., vol. 14, no. 8, p. 1800613, 2019.

[4] Puslit Bioteknologi, "Bioteknologi Beri Solusi Permasalahan Pangan, Energi, dan Obat-Obatan," Lembaga Ilmu Pengetahuan Indonesia, 2015. [Online]. Available: http://lipi.go.id/siaranpress/bioteknologi-beri-solusi-permas alahan-pangan-energi-dan-obat-obatan/13736. [Accessed: 19-Apr-2020].

[5] W. J. Thieman and M. A. Palladino, Introduction to Biotechnology. United States of America: Pearson Benjamin Cummings, 2010.

[6] R. D. Schmid and C. Schmidt-Dannert, Biotechnology. Germany: Wiley-VCH, 2016.

[7] T. K. Attwood, S. Blackford, M. D. Brazas, A. Davies, and M. V. Schneider, "A global perspective on evolving bioinformatics and data science training needs," Brief. Bioinform., vol. 20, no. 2, pp. 398-404, 2019.

[8] N. M. Luscombe, D. Greenbaum, and M. Gerstein, Review: What is Bioinformatics? An Introduction and Overview. New Haven, USA, 2001.

[9] X. Gu, B. Wu, and X. Xu, "Design, development, and learning in e-Textbooks: What we learned and where we are going," J. Comput. Educ., vol. 2, no. 1, pp. 25-41, 2015.

[10] N. Abdimital, "Creation of New Generation Textbooks for Technical Educational Institutions Based on Innovative Technologies," Eur. J. Res. Reflect. Educ. Sci. Vol, vol. 8, no. 5,2020 .

[11] L. Dick, W., Carey and J. . Carey, The Systematic Design of Instruction 7th Edition. New Jersey: Pearson Edu, Inc, 2009.

[12] L. Darling-Hammond, L. Flook, C. Cook-Harvey, B. Barron, and D. Osher, "Implications for educational practice of the science of learning and development," Appl. Dev. Sci., vol. 24, no. 2, pp. 97-140, 2020.

[13] J. M. Harackiewicz and S. J. Priniski, "Improving student outcomes in higher education: The science of targeted intervention," Annu. Rev. Psychol., vol. 69, pp. 409-435, 2018.

[14] S. Bal-Taştan, S. M. M. Davoudi, A. R. Masalimova, A. S. Bersanov, R. A. Kurbanov, A. V Boiarchuk, and A. A. Pavlushin, "The impacts of teacher's efficacy and motivation on student's academic achievement in science education among secondary and high school students," EURASIA J. Math. Sci. Technol. Educ., vol. 14, no. 6, pp.
$2353-2366,2018$

[15] L. Zapata-Cardona and L. M. M. Escobar, "Critical Citizenship in Colombian Statistics Textbooks," in Topics and Trends in Current Statistics Education Research, Springer, 2019, pp. 373-389.

[16] E. Knain, "Ideologies in school science textbooks," Int. J. Sci. Educ., vol. 23, no. 3, pp. 319-329, 2001.

[17] Menteri Pendidikan dan Kebudayaan Republik Indonesia, Salinan Lampiran Peraturan Menteri Pendidikan Dan Kebudayaan Republik Indonesia Nomor 8 Tahun 2016 Tentang Buku Yang Digunakan Oleh Satuan Pendidikan. 2016, pp. 1-12.

[18] Depdiknas, Panduan Pengembangan Bahan Ajar. Jakarta: Departemen Pendidikan Nasional, 2008.

[19] S. Akbar, Instrumen Perangkat Pembelajaran. Bandung: Remaja Rosdakarya, 2016.

[20] A. I. Suryani, Anwar, Hajidin, and I. Rofiki, "The practicality of mathematics learning module on triangles using GeoGebra," J. Phys. Conf. Ser., vol. 1470, no. 1, p. 012079, 2020, doi: 10.1088/1742-6596/1470/1/012079.

[21] S. Musilekwa and I. M. Mulenga, "Development of Social Studies Learners' Textbooks for Secondary Schools in Zambia," Development, vol. 10, no. 6, 2019.

[22] J. F. Trimmer, The New Writing with a Purpose. Boston: Houghton Mifflin, 2004

[23] S. J. Quaye, S. R. Harper, and S. L. Pendakur, Student engagement in higher education: Theoretical perspectives and practical approaches for diverse populations. Routledge, 2019.

[24] P. Smagorinsky, "The method section as conceptual epicenter in constructing social science research reports," Writ. Commun., vol. 25, no. 3, pp. 389-411, 2008.

[25] G. LoBiondo-Wood and J. Haber, Nursing research-e-book: methods and critical appraisal for evidence-based practice. Elsevier Health Sciences, 2017.

[26] A. P. P. Sari, M. Amin, and B. Lukiati, "Buku Ajar Bioteknologi Berbasis Bioinformatika Dengan Model ADDIE," J. Pendidik. Teor. Penelitian, Dan Pengemb., vol. 2, no. 6, pp. 768-772, 2017.

[27] E. DePoy and L. N. Gitlin, Introduction to Research E-Book: Understanding and Applying Multiple Strategies. Elsevier Health Sciences, 2019. 